\title{
Perceived Complex Image and Induced Image: Concordance or Discordance in the Case of the City of Tyre
}

\author{
Batoul TAMIM ${ }^{1}$, Walid ABOU-KHALIL ${ }^{2}$ and Eliane KHALIFE ${ }^{3}$ \\ ${ }^{1}$ Conservatoire National des Arts et Métiers, Paris, France \\ ${ }^{2,3}$ School of Business, Saint Joseph University, Beirut, Lebanon
}

Correspondence should be addressed to: Walid ABOU-KHALIL; walid.aboukhalil@usj.edu.Ib

Received date: 10 February 2020; Accepted date: 6 October 2020; Published date: 5 January 2021

Academic Editor: Afef Ammar Belaid

Copyright (C) 2021. Batoul TAMIM, Walid ABOU-KHALIL and Eliane KHALIFE. Distributed under Creative Commons Attribution 4.0 International CC-BY 4.0

\begin{abstract}
This research examines the image of a Lebanese tourist destination, the city of Tyre. In order to detect and analyze the existing differences between the complex image as perceived by the destination's visitors and the desired image by the city municipality, two complementary studies were carried out. A first qualitative study based on three interviews with officials within the municipality of Tyre was supplemented by a statistical analysis carried out with 118 tourists. The results obtained showed the existence of a significant divergence between the essential components of the perceived image and those of the desired image of the city, and by the same token the need for improvements at the operational and commercial levels to guarantee tourist satisfaction and arouse the interest of potential tourists toward this city.
\end{abstract}

Keywords: Induced Image, Perceived Complex Image, Tourist Destination, Tyre - Lebanon.

\section{Introduction}

Tourism marketing interests most countries and cities around the world and constitutes, for many of them, the basis of their national economy (Frochot and Legohérel, 2017). The tourism industry is booming but remains a huge challenge for many developing countries. In a context of global tourist competition, certain tourist destinations are trying to impose themselves by developing attraction strategies highlighting their strengths. Creating a strong image through notoriety and positioning becomes today for any destination a capital objective. Thus, the latter, which gives more importance to its competitive positioning, seeks to distinguish itself by offering a unique image (Bédard, 2011). The image of a tourist destination is a key element that improves its visibility on the world tourist map. This image requires a coherent strategy to enhance the city and it is no exaggeration to say that to exist, a tourist destination must be present on the world map of tourism practices (Piriou, 2011). Indeed, travelers choose a destination or a city, rather than a country; they are therefore looking for an experience recognized by its name and identity.

Hunt (1971) is the first to define the destination image as the impressions of a state held by people not residing in that same state. In the 21 st century, 
"selling an image" to tourists is no longer sufficient. This image must be "shared", more precisely the image "desired" by decision-makers must also be the image "experienced" by tourists (Barthès, 2005). In this regard, Piriou (2011) states that a tourist destination can only be considered "excellent" if it is co-constructed by the two parties, tourists and decision-makers. Thus, the image of a city is the combination of two images, that of the desired image and that of the perceived image. These two images must concur with each other and must convey the same vision of the city in question (Chon, 1991).

In Lebanon, the city of Tyre is trying, through the efforts of its municipality, to become a popular tourist destination in the eyes of visitors. Known for its rich historical heritage, it seeks to differentiate itself by creating a strong reputation in order to develop the attractiveness of its territory and to project a strong and positive image on a very competitive tourist market. In recent years and despite these efforts, the city's tourism activity has been declining. This city, which has impressive and enormous archaeological sites, cannot manage to exploit them properly, which considerably affects all the tourism players involved at all levels.

In this competitive environment, our research problem relates to the fact that the tourist activity of the seaside town of Tyre does not live up to its exceptional heritage and is only declining. The historical vestiges are underexploited there, while the town hall is satisfied with the work undertaken over the past five years. It considers that this regression is mainly due to the economic situation of the country regardless of the perception of the city by tourists who have visited it.

Based on the perception of the destination of Tyre from the point of view of the main members of its municipality as well as from the point of view of the tourists who have visited it, our objective is to identify and analyze the existing differences between the perceived and desired images of the city. In addition, we aim on the one hand to understand the situation and to identify the activities that the municipality implements in order to attract more tourists and on the other hand to understand how local and foreign tourists perceive this destination in terms of image and notoriety.

In order to meet our research objective, we proceeded in three stages. The first stage presents the theoretical framework of the research which essentially concerns the image of a tourist destination. The second stage details the research methodology. A qualitative study based on three interviews revealed the city's desired image by the municipality. This study was followed by a quantitative analysis conducted on a sample of 118 individuals who highlighted the perceived image of the city by its visitors and tourists. The third stage is based on the results and discussion of our analytical framework.

\section{Theoretical framework: Image of a tourist destination}

Based on previous work, we will first define and analyze the image of a tourist destination and then, in a second step, identify its various components.

\section{Definition of the image of a tourist destination}

The association of a positive and distinct image with a tourist destination is a very widespread phenomenon in the world which allows the city to occupy an important place in the mind of the traveler. This pushes destinations to adopt communication strategies with the aim of creating, enhancing and promoting a strong and satisfying image (Leisen, 2001). Thus, by conveying a favorable image of the territory, the destination sees its competitiveness increasing within a highly diversified tourism sector (Telisman-Kosuta, 1994).

Nowadays, cities are constrained to adopt tourism marketing and communication strategies in order to highlight their tourism assets (Baloglu and Magaloglu, 2001). Competition between territories exposes cities to the same business challenges; they have an image, a name, a positioning that they must develop in order to highlight their differences. As "destination image is strongly believed to influence a tourist's choice of destination" (Tasci and Gartner, 2007, p.419), it is then important to analyze the process of a tourist destination image formation as well as the image components and determinants (Jenkins, 1999).

In the literature, there is no consensus on a precise definition of the image of a tourist destination. According to Crompton (1979, p.18), it represents "the sum of beliefs, ideas, and impressions that a person has of a destination". Assael (1984, p.695) defined it as the "total perception of the destination that is formed by processing information from various sources over time". The research by Embacher and Buttle (1989 p.5) speaks of "ideas or conceptions held individually or collectively of the destinations under investigation". Furthermore, MacKay and Fesenmaier (1997, p.539) refer to "a composite of various products (attractions) and attributes woven into a total impression". The 
analysis of Pritchard (1998, p.36) refers the image of a tourist destination to a "visual or mental impression of a place, product or experience". Similarly, the works of Tapachai and Waryszak (2000, p.38) define it as " perceptions or impressions of a destination held by tourists with respect to the expected benefit or consumption values including functional, social, emotional, epistemic, and conditional benefits of a destination". Finally, Kim and Richardson (2003, p.218) represent it as a "totality of impressions, beliefs, ideas, expectations, and feelings accumulated towards a place over time".

We notice through this amalgam of definitions that several terms like "impressions", "perceptions", "ideas", "conceptions", "feelings", "expectations" and "beliefs" are repeated when it comes to defining the image of a tourist destination, which confirms its subjective, multidimensional and complex nature (Bigne, Sanchez and Sanchez, 2001). Within this perception, the definition of Lawson and Baud-Bovy (1977, p.3) was retained because it seems the most consistent with our study. The image of a tourist destination is then "the expression of all objective knowledge, impressions, prejudice, imaginations, and emotional thoughts an individual or group might have of a particular place".

The image of a destination plays a key role in the choice of the destination since it constitutes a decisive factor for the visitor, affects their decisionmaking as well as their future choices (Baloglu and McCleary, 1999; Hunt, 1975; Chon, 1990). This choice is linked to the capacity of the place to convey a positive image capable of arousing the interest of the tourist. The image will likewise guide the tourist behavior of the visitor (Hunt, 1975), influence the process of selecting the destination as well as their behavioral intentions (Chen and Tsai, 2007; Qu et al., 2011; Wang and Hsu, 2010). The tourism marketing strategy put in place by the destination plays an important role during the formation of this image, because it has a capital influence on the choice of the destination and must be placed at the center of the strategies of the destination in question. The formation of the image of a tourist destination results from several factors interacting together, such as physical, historical and cultural factors (Kotler et al., 2017).

Furthermore, the image of a tourist destination is also influenced by the culture and cultural distances shared by certain territories affecting the preferences and behavior of tourists (Assael, 1984; MacKay and Fesenmaier, 1997; Crotts, 2004). Being that culture is linked to the geographical origin of the traveler and the traditions and values of each individual, it is specific to each country. According to Richardson and Crompton (1988), this image changes depending on the nationality and origins of the tourist where several aspects and motivations intervene in a conscious or unconscious, direct or indirect way, during the formation of the image of a tourist destination (Moutinho, 1987; Baloglu, 1997; Gartner, 1993). It leads to an individual attitude towards the attributes of a destination according to knowledge and personal feelings (Moutinho, 1987).

The image of a tourist destination is then only the set of perceptions of the destination's individual attributes and the overall impression that it reflects (Echtner and Ritchie, 1991). It represents the beneficial attributes that a tourist city can offer and gives the latter an unparalleled competitive advantage (Gartner, 1989).

\section{The image's components of a tourist destination}

Gunn (1988) argues that the image of a tourist destination changes with the stages of the purchasing process, and that it is capable of confusing potential tourists and making their choice difficult. He distinguishes between three different images' components which are the organic image, the induced image and the complex image.

The organic image comes from the traveler's exposure to non-tourist information such as newspapers, magazine articles, television reports, films, friends' opinions, etc. It is the image formed in the mind of the visitor before having made the trip. It is often an incomplete or even erroneous image which can be influenced by the image of the country, and which is sometimes difficult to modify by tourism players.

The induced image is disseminated by the media or through the communication of tourism players such as advertisements, brochures, tourist guides and travel agencies. Its objective is to "sell the destination", to orient and inform the traveler, but also to act on the organic image initially formed and change it to encourage the tourist to travel. The media coverage of the destination therefore provides a multitude of images encouraging tourists' mobility through numerous information that will help them to project themselves in the chosen place (Violier, 2007).

The complex image is formed following the visitor's journey; it plays a role in the appreciation of the destination as well as in its evaluation and is capable of modifying the organic and induced images. It is from their stay that the tourist can 
develop a positive or negative image of the place visited (Frochot and Legohérel, 2017). Therefore, there is a big difference between the image formed before and after the visit of the destination which is explained by the lack of knowledge and information on the part of the traveler. The complex image is the perceived tourist's destination image formed after a stay, which comes from the personal experience of the tourist, leaving them the possibility of correctly evaluating the destination in question (Marchat and Camelis, 2017). Thus, the complex image which in the context of this research will be called perceived complex image, reflects the true image of a tourist destination. It is influenced by the number of visits and by the length of the stay (Chon, 1991; Crompton, 1979).

The perceived complex image also makes it possible to appreciate the degree of satisfaction or dissatisfaction of the visitor following the provision of the tourist service (Oliver, 1997). It represents the reality of the tourist destination and plays a key role in the recommendations and revisiting intentions which, according to $\mathrm{Qu}$ et al. (2011), are at the origin of the visitor's loyalty (Bigne, Sanchez and Sanchez, 2001; Lee, 2003; Oliver, 1997). To understand the behavior of tourists, Chi and Qu (2008) and Prayag and Ryan (2012) consider that positive word-of-mouth, the intention to revisit the destination and to recommend it to others, represent a relevant indicator of loyalty. The perceived complex image is also capable of generating emotions and promoting attachment, even creating a strong link between tourists and the destination (Moore and Graefe, 1994). Some authors such as George and George (2004), George and Alexandru (2005) and Veasna and Huang (2013) have argued that the image is capable of provoking "strong feelings" which strengthen the attachment and loyalty of the traveler. These feelings developed by visitors represent a real source of emotional ties (Yuksel, Yuksel and Bilim, 2010).

All the authors agree that the reality of a tourist destination may be different from its image before the visit because the image is a reflection of the visitor's subjective interpretation of reality. The numerous definitions of the image reveal the complexity of this concept. At the end of this review, it would be prudent to explore, through the tourist's eyes, the overall picture of a destination. This multidimensional and subjective image is, according to Akama and Kieti (2003) and Stylidis, Shani, and Belhassen (2017), the basis of the success of any destination in attracting tourists.
Methodological framework: Case of the city of Tyre

\section{The city of Tyre}

Called "Queen of the Seas", the city of Tyre has a rich historical and cultural heritage. This Phoenician city contains exceptional archaeological sites and ancient vestiges listed as UNESCO heritage. Tyre has a remarkable tourist potential, which the members of the municipality try to emphasize in order to attract and charm tourists. They also attempt to exploit this potential and develop it through the diversification of the tourist activities that are offered in the city. This literature review leads us to formulate our main question which this research aims to answer:

Given the remarkable tourist potential of the city of Tyre, what are the elements of tourist attractiveness that decision-makers must strengthen so that Tyre occupies the place of a competitive destination and of which the perceived complex image reflects the positioning aspired by the municipality?

\section{Methodology}

The research objective determines the methodology to be adopted (Creswell, 2009; Fortin, Côté and Fillion, 2005). In this research, we favored the triangulation which consists in systematically associating in the same study qualitative methods with quantitative methods (Caillaud and Flick, 2016). According to Denzin and Lincoln (2017), triangulation is the simultaneous display of several reflected realities. This allows information and data to be gathered from different sources by making use of more than one tool. The objective is to compare them in order to be able to extract the information that gives an answer to our research questioning. As there are different research models based on mixed methods (Tashakkori and Teddlie, 2010; Creswell, 2009), we have adopted a model based on the principle of complementarity. Thus, two studies, one qualitative and one quantitative, were carried out to capture and analyze the perception of tourists visiting the city of Tyre and thereby respond to the research problem.

\section{The Qualitative Study}

An exploratory study was carried out during the month of April 2019 through three semistructured interviews based on an interview guide (appendix 1) whose literature review facilitated its development. These interviews were conducted with the deputy director of the municipality of 
Tyre (DDM), the head of the tourism department in the municipality (HTD) as well as the director of the archaeological sites of Tyre and South Lebanon (DAS). The two interviews with DDM and HTD took place within the municipality. The third one which was carried out with DAS, took place in his office located in the heart of the city's tourist sites. The objective was to understand the image of the city as desired by the municipality and to extract information about the various tourist attractions of the city. The processing of the data collected was carried out through content analysis (Bardin, 2013). Interviews were recorded after obtaining consent from the interviewees. Each interview was conducted face to face and lasted between 60 and 90 minutes. They were all very rich in information. After a careful reading of all the comments collected, a thematic analysis was carried out to highlight "meaning units - key elements", the occurrence of which is significant. The main key elements have been grouped into variables which were used to formulate the hypotheses to be tested as well as to develop the questionnaire (appendix 2) that served to collect the data for the quantitative study.

\section{The Quantitative Study}

The quantitative study carried out on a sample of 118 individuals during the period between April 15, 2019 and June 10, 2019, formed the second part of this research. The descriptive statistical analysis developed made it possible to present the socio-demographic characteristics and the motivations of the people belonging to the sample, then through an inferential statistical analysis to test the hypotheses deduced from the second part of a questionnaire to which tourists visiting the city of Tyre were able to respond during their stay. This questionnaire was the tool that helped detect the perceived complex image of the city by tourists. It was developed following the results obtained by various interviews carried out beforehand.

The questionnaire comprising 18 questions was developed in French and English and divided into three sections. The first section contains questions that concern the visitor's stay and motivations. The second part includes 18 affirmations for the assessment of the tourists' opinions vis-à-vis the components of the perceived image of the city of Tyre. These items are incorporated into a Likert scale comprising 5 response options (ranging from 1 "strongly agree" to 5 "strongly disagree") for which the respondent specifies their degree of agreement. The third part includes identification questions that concern the tourist.

\section{Questionnaire Pretest}

Before administering the questionnaire to our sample, we carried out a pretest on eleven individuals. The objective was to increase "the validity of the survey data, by reducing measurement errors, and thus increase the validity of derived conclusions" (Snijkers, 2002, p.224).

By focusing on how people answered and interpreted our questions, this pretest provided us with the most direct evidence of the validity of the questionnaire data for most items. Our procedure was based on the retrospective cognitive interview approach where we asked verbal questions to all participants after completing the questionnaire.

\section{Questionnaire Administration}

The questionnaire was administered face to face to tourists and visitors in the hotels in Tyre where they resided (25 respondents) as well as in the tourist and archaeological sites they frequented (40 respondents). The same questionnaire, created on Google Forms, was administered online to visitors who expressed their desire to respond later (53 respondents). There were no refusals and all questionnaires were filled out completely.

These two complementary studies aimed to compare the perceived image of Tyre by tourists with the image desired by members of the municipality and those responsible for the city's tourist sites. This approach allowed us to make this comparison and to formulate useful recommendations on the positioning of the city.

\section{Procedure}

The sampling method used for the qualitative study was purposive (Patton, 1990). The choice of participants was made according to the objectives of the research. It was carried out on the basis of two particular characteristics which are essentially the competence and experience of the interviewees (Fortin, Côté and Fillion, 2005) in the field of tourism in Tyre. The key informants in this sample were selected on the basis of the richness and relevance of the information. However, the number of these participants was not decided in advance because statistical representativeness was not essential. The size of the sample (three people questioned) depended on the saturation of information (Bertaux, 1981; Savoie-Zajc, 1997) where at the end of the third interview, no new information was observed in the data.

The quantitative study sample was chosen randomly and on the basis of the definition given 
by the World Tourism Organization (UNWTO) on tourism as leisure, business or other activities which "people undertake during their travels and stays in places outside of their usual environment for a consecutive period of not more than one year" (Lozato-Giotart, Leroux and Balfet, 2014, p.6). We therefore selected the respondents in a random manner. These were "visiting" travelers met in Tyre; they are defined by the same authors as being all travelers or tourists whose visit does not involve a night spent, those who spend three consecutive nights and those whose trip involves at least four consecutive nights away from their usual place of residence (Lozato-Giotart, Leroux and Balfet, 2014). They included inbound tourists and Lebanese living either in Lebanon or abroad.

Several authors agree that variables, with fivepoint or more ordinal Likert-type scales, can often be considered continuous and used on this basis without this affecting the analysis in which the researcher plans to use them (Norman, 2010; Sullivan and Artino, 2013; Chimi and Russel, 2009). For continuous data, Bartlett, Kortrik and Higgins (2001) determined the minimum sample size to be 119 for a population $\geq 10,000$ and for a level $\alpha=0.05$. The choice of our sample composed of 118 individuals corresponds to this categorization.

The presentation of the results of the qualitative study
The data gathered through the interviews made it possible to highlight the image of the city as projected by the municipality. They have also made it possible to identify the elements on which the city's tourism potential is based. They were grouped by theme and analyzed using a thematic analysis grid. The three interviewees highlighted several key elements that make up tourism in Tyre. These elements, grouped by theme and illustrated by verbatim taken from the words of the interviewees, are summarized in Table 1.

DDM and HTD have agreed to affirm that the city of Tyre has been placed in the first rank in the tourist level for the year 2018 and that it is part of one of the most beautiful tourist cities of Lebanon thanks to its beach, its old neighborhoods, its souks and its traditional port. They also specified that despite its small size, the city of Tyre contains a diversity of cultural and seaside tourist activities. For his part, DSA explained to us that beside the number and diversity of the civilizations which crossed the city of Tyre, the peculiarity of the archaeological sites of the city lies not only in their location and size, but also in their conservation because they are ruins that date back over a thousand years. All interviewees agree that the measures proposed by the municipality for the enhancement and protection of the city's heritage are sufficient. However, they attribute the weakness of the city's tourist frequentation to the context of economic and financial crisis which prevails in the country.

Table 1: The topics covered illustrated with an extract from verbatim and supplemented by the highlighted key elements

\begin{tabular}{|c|c|c|}
\hline Themes & Verbatim & Key elements \\
\hline Historical heritage & $\begin{array}{l}\text { "Very rich historical heritage registered with UNESCO." } \\
\text { "It is the main tounist attraction of the city of Tyre." } \\
\text { "Tyre, an inportant image in history, across many civilizations and } \\
\text { archaeological eras." }\end{array}$ & $\begin{array}{l}\text { Archaeological sites } \\
\text { included in the } \\
\text { UNESCO World } \\
\text { Heritage List. }\end{array}$ \\
\hline $\begin{array}{l}\text { Diversified tourism in } \\
\text { Tyre }\end{array}$ & $\begin{array}{l}\text { "Tourism in Tyre is very diverse and is mainly based on seaside and } \\
\text { cultural activities, as well as several events and festivals." } \\
\text { "Presence of neighborhoods and souk with traditional characteristics, but } \\
\text { also the page and the port." }\end{array}$ & $\begin{array}{l}\text { Very diverse tourism. } \\
\text { Several tourist, cultural } \\
\text { and artistic activities. }\end{array}$ \\
\hline Cultural diversity & $\begin{array}{l}\text { "Cultural and religious diversity in Tyre, multicultural community life, civil } \\
\text { peace, freedom of expression and brotherhood policy." }\end{array}$ & $\begin{array}{l}\text { Cultural and religious } \\
\text { diversity. }\end{array}$ \\
\hline Tyre festival & "Various events, very important for tourism, such as the Tyre Festival." & $\begin{array}{l}\text { Long-awaited } \\
\text { traditional annual event. }\end{array}$ \\
\hline Nightlife & $\begin{array}{l}\text { "The nightlife in Tyre is very lively, the restaurants stay open until } 2 \text { a.m. } \\
\text { during the summer and the kiosks never close." }\end{array}$ & $\begin{array}{l}\text { Very nice atmosphere, } \\
\text { very lively nightlife. }\end{array}$ \\
\hline Old neighborhoods & $\begin{array}{l}\text { "Tyre is known for its old quarters like "Hara", its old "Souk" and its oid } \\
\text { "Sidonian" port, which retain their old characters." }\end{array}$ & $\begin{array}{l}\text { Souk and Port with a } \\
\text { traditional character. }\end{array}$ \\
\hline Beach & $\begin{array}{l}\text { "The beach is the main asset of the city of Tyre." } \\
\text { "It is one of the best and cleanest beaches in Lebanon." } \\
\text { "Location of archeoological sites facing the beach." }\end{array}$ & $\begin{array}{l}\text { Dynamic seaside } \\
\text { tourism and very clean } \\
\text { beach. }\end{array}$ \\
\hline Hotels & $\begin{array}{l}\text { "Tyre hotels offer satisfactory service and are checked regularly." } \\
\text { "12 Very varied hotels, motel, guest house ... and the architecture also } \\
\text { varies." }\end{array}$ & $\begin{array}{l}\text { Variety of hotels and } \\
\text { motels with satisfactory } \\
\text { service. }\end{array}$ \\
\hline Restaurants & $\begin{array}{l}\text { "Daily and regular quality control at the culinary level." } \\
\text { "90 Restaurants very controlled in terms of food quality and hygiene." }\end{array}$ & $\begin{array}{l}\text { Regular culinary } \\
\text { control. Good and } \\
\text { healthy food. }\end{array}$ \\
\hline Cleanliness of the city & "City cleaning control to ensure the city's level of cleanliness." & $\begin{array}{l}\text { Regular and daily street } \\
\text { cleaning. }\end{array}$ \\
\hline Security & $\begin{array}{l}\text { "Tyre is a very sectire city, which is nice for its visitors." } \\
\text { "Safety and security are important to keep the city order." }\end{array}$ & $\begin{array}{l}\text { City secured by the } \\
\text { presence of police. }\end{array}$ \\
\hline Parking lots & "Lack of parking because Tyre is a geographically limited city." & $\begin{array}{l}\text { A lack of space for } \\
\text { parking lots. }\end{array}$ \\
\hline Road congestion & "Complicated traffic and a lot of traffic jams." & $\begin{array}{l}\text { Serious traffic jam } \\
\text { problems. }\end{array}$ \\
\hline Local population & $\begin{array}{l}\text { "Very hospitable and friendly local population with very welcoming locals, } \\
\text { easy interactions and exchanges with people." }\end{array}$ & $\begin{array}{l}\text { Welcoming and } \\
\text { hospitable inhabitants. }\end{array}$ \\
\hline Pedestrians & $\begin{array}{l}\text { "Presence of sidewalks everywhere in Tyre." } \\
\text { "The Corniche makes walking in the city pleasant." }\end{array}$ & $\begin{array}{l}\text { City welcoming to } \\
\text { pedestrians, presence of } \\
\text { sidewalks and cornices. }\end{array}$ \\
\hline Prices & $\begin{array}{l}\text { "Prices suitabie for all economic and social classess." } \\
\text { "Entrances to sites set by the Ministry of Culture." }\end{array}$ & $\begin{array}{l}\text { Prices suitable for all } \\
\text { economic and social } \\
\text { classes. }\end{array}$ \\
\hline
\end{tabular}

Batoul TAMIM, Walid ABOU-KHALIL and Eliane KHALIFE (2021), Journal of Marketing Research and Case Studies, DOI : 10.5171/2021.773594 
These statements collected helped to illustrate the city's desired tourist image. They were of fundamental importance for the development of this research. Their interpretation made it possible to reconstruct the induced image of Tyre and to reveal its tourist identity.

\section{Variables identification and hypotheses development}

Following the key elements collected by the qualitative study, the following variables were identified:

Historical heritage, diversified tourism, cultural diversity, Tyre festival, nightlife, old neighborhoods, beach, hotel services, cleanliness of the city, security, parking lots, road congestion, local population hospitality, tourist sites, cuisine, sidewalks, liveliness and prices.

The hypotheses formulated according to these variables are:

H1 The historical heritage of Tyre is a component of the city's image perceived as positive

H2 Tourist sites in Tyre are a component of the city's image perceived as positive

H3 The diversification of tourism in Tyre is a component of the city's image perceived as positive

H4 Cultural diversity in Tyre is a component of the city's image perceived as positive

H5 Tyre Festival is a component of the city's image perceived as positive

H6 Nightlife in Tyre is a component of the city's image perceived as positive

H7 The old and traditional character of Tyre's neighborhoods constitutes a component of the city's image perceived as positive

H8 Tyre beach is a component of the city's image perceived as positive

H9 The cleanliness of the city of Tyre constitutes a component of its image perceived as positive

H10 The services offered in Tyre's hotels constitute a component of the city's image perceived as positive
H11 Healthy local cuisine is a component of the city's image perceived as positive

H12 Parking lots in Tyre are a component of the city's image perceived as negative

H13 The welcoming and friendly character of Tyre's local population constitutes a component of the city's image perceived as positive

H14 Liveliness in Tyre is a component of the city's image perceived as positive

H15 Road congestion in Tyre is a component of the city's image perceived as negative

H16 Sidewalks in Tyre constitute a component of the city's image perceived as positive

H17 Safety in Tyre is a component of the city's image perceived as positive

H18 The low cost of living in Tyre is a component of the city's image perceived as positive

\section{Analysis and results' interpretation of the quantitative study}

In a first step, descriptive statistical analysis on the socio-demographic and motivational aspects of the sample of tourists and visitors to Tyre was carried out. In a second step, the univariate hypotheses were tested using inferential statistical analysis.

\section{Descriptive analysis of socio-demographic data}

The descriptive statistical results reveal that $70 \%$ of the respondents are between 18 and 34 years of age and that $95 \%$ of these "visiting" tourists have a university education and are almost equally divided between women (53\%) and men ( $47 \%$ ). $53 \%$ of the respondents are Lebanese living in their native country and $70 \%$ are single. As for the monthly income of tourists, more than $50 \%$ of them have a monthly salary which does not exceed 1500 US dollars while that of only $18 \%$ exceeds 3000 US dollars

\section{Descriptive analysis of tourists' motivations}

$33 \%$ of tourists have visited the city once and $55 \%$ twice. Almost $60 \%$ of the respondents spent only one day and $84 \%$ were motivated to visit it because of its natural, tourist and cultural attractions. Of the visitors $65 \%$ got to know the city through word 
of mouth while $18 \%$ got to know it through brochures and $16 \%$ through the Internet and social networks. $42 \%$ of the respondents came with family and $43 \%$ with friends.

These results allow us to deduce that the general profile of the tourist visiting Tyre is that of an independent and educated man or woman belonging to a young generation and who seeks to discover, learn and enjoy the tourist attractions in Tyre. This "visiting" tourist is of the excursionist type and is strongly motivated by the natural, cultural and tourist attractions of the city. They are usually accompanied by either family members or friends. They got to know Tyre mostly through word of mouth but very little through written material, online or through social media.

\section{Sampling Adequacy}

The Kaiser-Meyer-Olkin test of sampling adequacy (KMO) is performed to check whether the sample is large enough (Habing, 2003). The sample is adequate if the KMO value is greater than 0.5 (Durand, 2003; Habing, 2003). The Kaiser - Meyer - Olkin (KMO) and Bartlett sphericity tests which were carried out gave respective widely accepted results of 0.715 and ISB $<0.5$.

\section{Scale Reliability}

The reliability, which indicates the degree of internal consistency with which the instruments used measure the studied construct, was evaluated by Cronbach's alpha. According to Bland and Altman (1997), a factor is reliable if the value of Cronbach's alpha varies between 0.70 and 0.95 with 0.90 as the maximum recommended value (Streiner, 2003), and above which one should consider reducing the number of items (Carricano and Poujol, 2008, p.53). The $\alpha$ value we obtained is 0.795 , which shows a good level of internal consistency. Since our scale is reliable, there is no longer any need to purify the scale in order to increase its quality, if items were deleted.

\section{Hypothesis Tests}

18 hypotheses deduced from the variables previously identified were tested. The objective was to determine whether the studied variables formed components of the image perceived by tourists, and to subsequently compare the results of this analysis with the image desired by the municipality of Tyre, in order to derive conclusions. These univariate hypotheses were not tested through associations but through comparisons between the responses of the two groups of tourists and "visiting" travelers who made up the sample of 118 individuals.

The approach followed is that recommended by Gosavi (2015). We used the binomial distribution to develop a test of statistical significance. We first inverted the response value for each of the elements and then combined the five response categories into three (agreement, disagreement, neutral) according to two groups of respondents $L_{1}$ and $L_{2}$ and a group of "neutral" respondents alternating in the statistical analysis with both of these two groups. The proportions of respondents in each group were calculated in order to test the hypotheses $H_{0}: p_{1} \leq p_{2}$ and $H_{1}: p_{1}>p_{2}$ at the error rate $\alpha=0.05$ on the basis of the overlap or nonoverlap of the values delimiting the confidence intervals for the proportions of the groups studied in the sample $p_{i}$ via the following equation:

$$
\left(p_{i}-z \frac{\alpha}{2} \frac{\sqrt{p_{i}\left(1-p_{i}\right)}}{n}, p_{i}+z \frac{\alpha}{2} \frac{\sqrt{p_{i}\left(1-p_{i}\right)}}{n}\right) * 100
$$

Where $p_{i}$ is the estimated proportion of the population belonging to group $i$ and $n=L_{1}+L_{2}$ which denote the total number of respondents.

The results obtained will be accepted because the sample size is $>100$ (Gosavi, 2015). Based on the overlap of the values of the minimum and maximum limits of the confidence intervals, these results allowed us to reject $H_{0}$ for the hypotheses $\mathrm{H}_{2}, \mathrm{H}_{3}, \mathrm{H}_{4}, \mathrm{H}_{5}, \mathrm{H}_{6}, \mathrm{H}_{7}, \mathrm{H}_{8}, \mathrm{H}_{11}, \mathrm{H}_{12}, \mathrm{H}_{13}, \mathrm{H}_{15}, \mathrm{H}_{16}, \mathrm{H}_{17}$ and $H_{18}$. However, we failed to reject $H_{0}$ for hypotheses $\mathrm{H}_{1}$ (in the second step of the analysis) and $\mathrm{H}_{10}$ (in the third step of the analysis).

For hypotheses $\mathrm{H}_{9}$ and $\mathrm{H}_{14}$, the statistical analysis carried out in the first step did not allow a final conclusion to be drawn as to whether the null hypothesis is true or false.

The following tables give us the different values and results obtained following the inferential analysis carried out in steps 2 and 3 and which allowed us to draw statistical conclusions for the 16 remaining hypotheses. 
Table 2: $2^{\text {nd }}$ step of inferential analysis

\begin{tabular}{|c|c|c|c|c|c|}
\hline Hypothesis & CI $p_{1(A) \_}$Min.Val & CI $p_{1(\Lambda) \_ \text {Max.Val }}$ & CI $p_{1(\mathbf{B}) \_}$Min.Val & CI $p_{1(\mathrm{~B}) \_}$Max.Val & Result \\
\hline H1 & 97.50 & 100.81 & -0.81 & 99.11 & $H_{0}$ is not rejected \\
\hline $\mathrm{H} 2$ & 95.98 & 100.63 & -0.63 & 94.70 & $\rightarrow$ step 3 \\
\hline $\mathrm{H} 3$ & 95.98 & 100.63 & -0.63 & 83.68 & $\rightarrow$ step 3 \\
\hline $\mathrm{H} 4$ & 93.34 & 99.88 & 0.12 & 81.23 & $\rightarrow$ step 3 \\
\hline $\mathrm{H} 5$ & 92.13 & 99.40 & 0.60 & 52.79 & $\rightarrow$ step 3 \\
\hline H6 & 93.34 & 99.88 & 0.12 & 64.28 & $\rightarrow$ step 3 \\
\hline H7 & 97.50 & 100.81 & -0.81 & 94.87 & $\rightarrow$ step 3 \\
\hline $\mathrm{H} 8$ & 95.98 & 100.63 & -0.63 & 95.55 & $\rightarrow$ step 3 \\
\hline $\mathrm{H} 10$ & 95.98 & 100.63 & -0.63 & 57.41 & $\rightarrow$ step 3 \\
\hline H11 & 95.98 & 100.63 & -0.63 & 92.16 & $\rightarrow$ step 3 \\
\hline $\mathrm{H} 12$ & 93.34 & 99.88 & 0.12 & 75.30 & $\rightarrow$ step 3 \\
\hline H13 & 97.50 & 100.81 & -0.81 & 93.18 & $\rightarrow$ step 3 \\
\hline H15 & 93.34 & 99.88 & 0.12 & 68.52 & $\rightarrow$ step 3 \\
\hline $\mathrm{H} 16$ & 87.58 & 97.16 & 2.84 & 64.96 & $\rightarrow$ step 3 \\
\hline $\mathrm{H} 17$ & 88.68 & 97.76 & 2.24 & 76.57 & $\rightarrow$ step 3 \\
\hline $\mathrm{H} 18$ & 92.13 & 99.40 & 0.60 & 83.30 & $\rightarrow$ step 3 \\
\hline
\end{tabular}

Table 3: $3^{\text {rd }}$ step of inferential analysis

\begin{tabular}{|c|c|c|c|c|c|}
\hline Hypothesis & CI $p_{1(\mathrm{~A})}$ Min.Val & CI $p_{1(\mathrm{~A}) \_ \text {Max.Val }}$ & CI $p_{1(\mathbf{B}) \_ \text {Min.Val }}$ & CI $p_{1(\mathbf{B}) \_ \text {Max.Val }}$ & Result \\
\hline $\mathrm{H} 2$ & 89.81 & 98.33 & 1.67 & 10.19 & $H_{0}$ is rejected \\
\hline $\mathrm{H3}$ & 76.28 & 89.82 & 10.18 & 23.72 & $H_{0}$ is rejected \\
\hline $\mathrm{H} 4$ & 74.33 & 88.38 & 11.62 & 25.67 & $H_{0}$ is rejected \\
\hline $\mathrm{H} 5$ & 44.39 & 62.39 & 37.61 & 55.61 & $H_{0}$ is rejected \\
\hline $\mathrm{H} 6$ & 55.77 & 73.05 & 26.95 & 44.23 & $H_{0}$ is rejected \\
\hline $\mathrm{H} 7$ & 89.81 & 98.33 & 1.67 & 10.19 & $H_{0}$ is rejected \\
\hline $\mathrm{H} 8$ & 90.95 & 98.88 & 1.12 & 9.05 & $H_{0}$ is rejected \\
\hline $\mathrm{H} 10$ & 47.84 & 65.72 & 34.28 & 52.16 & $H_{0}$ is not rejected \\
\hline $\mathrm{H} 11$ & 86.50 & 96.55 & 3.45 & 13.50 & $H_{0}$ is rejected \\
\hline $\mathrm{H} 12$ & 67.66 & 83.19 & 16.81 & 32.34 & $H_{0}$ is rejected \\
\hline $\mathrm{H} 13$ & 87.58 & 97.16 & 2.84 & 12.42 & $H_{0}$ is rejected \\
\hline $\mathrm{H} 15$ & 60.27 & 77.02 & 22.98 & 39.73 & $H_{0}$ is rejected \\
\hline $\mathrm{H} 16$ & 59.37 & 76.23 & 23.77 & 40.63 & $H_{0}$ is rejected \\
\hline $\mathrm{H} 17$ & 71.44 & 86.19 & 13.81 & 28.56 & $H_{0}$ is rejected \\
\hline $\mathrm{H} 18$ & 77.27 & 90.53 & 9.47 & 22.73 & $H_{0}$ is rejected \\
\hline
\end{tabular}

\section{Discussion of Results}

The comparison of the results of the quantitative analysis with those of the qualitative study made it possible to highlight the points of differences and similarities between the statements made by the municipality officials and the opinions of tourists concerning the city's tourist activity. It shows that the image desired by the municipality matches in most of its aspects the image perceived by visitors. However, two aspects which are not consistent demonstrate a divergence between the desired image and the perceived one.

For tourists, Tyre is a city perceived as having a traditional aspect through its old neighborhoods, a remarkable beach and impressive sites with festivals considered important events, and in which tourism is diverse and the nightlife is pleasant. Tyre is also perceived as a city of cultural plurality, secure and welcoming to pedestrians with a friendly population and a healthy local cuisine and where life is not expensive. However, the historical heritage of the city is not perceived as being very rich and the hotel services not as satisfactory. In addition, the problems of parking lots and traffic jams are perceived as important.

According to the existing literature, the tourist product is defined as any tangible good or service that can be acquired during a trip to satisfy a need or desire (Kotler et al., 2017), tourist attraction as a sight associated with a marker and a tourist (MacCannell, 1976) and public service is defined by the Collins Dictionary as 'something such as health care, transport,

or the removal of waste which is organized by the government or an official body in order to benefit all the people in a particular society or community'. For his part, Suchman (1968) describes it as a professional form of activity dedicated to social planning and change. Besides and according to Griffero (2013), the atmosphere 
of a city results from a gathering of factors such as geographical-climatic situation, historical and socioeconomic condition, architecturalinfrastructural quality, value expressiveness, language and nutrition.

Table 4 groups the different components of the image perceived into four main groups: atmosphere of the city, public services, tourist attractions and tourist products. The two components of the perceived image which are highlighted in grey namely the historical heritage and the hotel services are the elements on which tourists and Tyre's municipal officials disagreed.

Table 4: Grouping of the perceived image's components into groups

\begin{tabular}{|l|l|}
\hline \multicolumn{1}{|c|}{ Group } & Components of the perceived image \\
\hline \multirow{4}{*}{ Atmosphere of the city } & Cost of living \\
\cline { 2 - 2 } & Cuisine \\
\cline { 2 - 2 } & Hospitality \\
\hline \multirow{4}{*}{ Public services } & Parking lots \\
\cline { 2 - 2 } & Safety \\
\cline { 2 - 2 } & Sidewalks \\
\cline { 2 - 2 } & Traffic jams \\
\hline \multirow{4}{*}{ Tourist attractions } & Beach \\
\cline { 2 - 2 } & Cultural diversity \\
\cline { 2 - 2 } & Historical heritage \\
\cline { 2 - 2 } & Tourist sites \\
\cline { 2 - 2 } & Traditional neighborhoods \\
\cline { 2 - 2 } & Tyre Festival \\
\hline \multirow{2}{*}{ Tourist products } & Hotels \\
\cline { 2 - 2 } & Nightlife \\
\hline
\end{tabular}

Tyre's image as a tourist city needs to be improved. As the basis of tourism in this city is service in its various aspects, it must be materialized so that it adds value to its overall image. Tourist attractions are perceived to be satisfactory, however the Municipality of Tyre must, drawing conclusions from the results of this study, make changes in terms of service and marketing in order to strengthen the attraction of the city and the value of its tourist products. The creation of public parking lots and the organization of traffic by the municipal police and the establishment of adequate signage in the streets is important to facilitate the stay of visitors and tourists. The installation of explanatory panels as well as the accessibility of brochures and other tourist information within and outside the sites remain a great necessity because this will allow better visibility of tourist attractions and products. The performance of services in existing hotels based on the aspirations of current and potential customers, or even the creation of new hotels, must be a priority. In addition, the historical heritage of Tyre is not highlighted, thus communication must focus on this aspect through strong media coverage both locally and internationally.
We deduce from the results obtained from the survey that many tourists did not have the opportunity to visit the whole city and explore its

historical heritage or even to get to know its hotels and their services because a large number of them were excursionists who went to spend the day and could not attend all the places in the city; which prevented them from grasping those elements.

Finally and on a theoretical level, this work confirms the existence of several tourist destinations' images (induced and complex image) which differ from each other and underlines the importance of the perceived complex image for a destination. The latter, which is formed following a tourist's stay, plays a key role in determining the degree of visitor satisfaction or dissatisfaction as reported by Oliver (1997), the intention of recommending and revisiting the place (Bigne, Sanchez and Sanchez, 2001) and the tourist's intention of being loyal to this place (Lee, 2003). 
The main purpose of this research was to detect and analyze the existing differences between the perceived image and the desired image and to highlight the elements of tourist attractiveness of the city in order to enlighten the municipality's members on the reality of tourism in Tyre. It is therefore essential to inform tourism decisionmakers of the differences that have emerged in order to encourage them to improve and strengthen the city's tourism situation, and to quickly unify its image. It has proved necessary and urgent in a highly competitive environment, to make a clear and lasting repositioning of this destination in order to guarantee a unique image that would produce satisfaction among current and potential tourists.

\section{Conclusion}

The image of a tourist destination is the central theme of this research, which studied the possibility of divergence between the induced image and the perceived complex image of a tourist destination. It also highlighted the importance of the perceived image and its influence on the tourist activity of a city.

Tyre is a Lebanese Phoenician city with a remarkable tourist potential. Despite its exceptional assets and the efforts of the municipality's members, this city is struggling to occupy the tourist place it deserves. Through two studies, one qualitative and one quantitative, the perceptions of decision-makers and tourists visiting the city were captured and analyzed to determine possible recommendations.

Historical heritage is an integral part of the elements that influence the perception of a tourist destination. The perception by tourists of Tyre's heritage - a key attraction of the city - is not as the municipality's council desires it to be. It would therefore be appropriate for the tourism industry to take more account of this cultural resource and develop sustainable actions for its preservation. Such actions prove to be profitable and beneficial in the long term for all tourism players.

The opinions of tourists visiting a tourist destination represent an essential source of progress for the city in question. On the basis of these ideas, it is essential for any tourist destination to develop a strong and unique image and a solid and clearly legible positioning operationalized by a set of communication and marketing elements that will help attracting tourists and meeting their expectations, thus ensuring a level of satisfaction that makes them revisit this city.
Our study shows the need for a tourist destination to adapt the induced image to the perceived complex image. While the image multidimensional effect is difficult to manage, ongoing and largescale visitors expectations surveys conducted by municipalities can be helpful.

Close collaboration between municipal decisionmakers, service providers and residents of a tourist destination is recommended. Closely associating and involving the players concerned in the design and management of all tourist activities and putting them at the center of public action is part of participatory management approaches. These approaches, which facilitate the development of the various local resources, guarantee acceptable improvements that are suited to their context of implementation.

A strong idea of these participatory approaches is to put the values and preferences of the actors at the center of public action because the mixture of values, of experts and of society should normally be more realistic than values of society normatively scrutinized by experts (Wagle, 2000).

But participation is demanding and not without risk. There is no guarantee that a participatory approach automatically leads to better solutions and decisions than another more authoritarian approach. Participation can even, in some cases, block the decision-making process and therefore lead to the opposite effects to those which were sought. Public participation in public decisions is therefore a necessary element, but not sufficient and it is very important to use these participatory processes with a lot of discernment. This integration of the proposed tool into a more global participatory approach is the logical follow-up to the work we have done, and the challenge now lies in the practical design and organization of a participatory process.

In line with this study, several perspectives for further research will be possible. What about the divergence between the image induced and the image perceived by local tourists and that perceived by foreign tourists? To conclude, it might also be useful to think about measures and procedures to be implemented that can help correct misperceptions of the image of a tourist destination.

\section{References}

- $\quad$ Akama, J. S. and Kieti, D. M. (2003), 'Measuring Tourist Satisfaction with Kenya's Wildlife Safari: a Case Study of Tsavo West National Park', Tourism Management, 24 (1), 73-81. 
- Assael, H. (1984), Consumer Behavior and Marketing Action, Kent Publishing, Boston.

- Baloglu, S. (1997), 'The Relationship between Destination Images and Sociodemographic and Trip Characteristics of International Travelers', Journal of Vacation Marketing, 3 (3), 221-233.

- Baloglu, S. and Mangaloglu, M. (2001), 'Tourism Destinations Images of Turkey, Egypt, Greece, and Italy as Perceived by USBased Tour Operators and Travel Agents', Tourism Management, 22 (1), 1-9.

- Baloglu, S. and McCleary, K. W. (1999), 'A Model of Destination Image Formation', Annals of Tourism Research, 6 (4), 868-897.

- Bardin, L. (2013), L'Analyse de Contenu, Presses Universitaires de France, Paris.

- Bartlett, J. E., Kortrik, J. K. and Higgins, C. (2001), 'Organizational Research: Determining the Appropriate Sample Size for Survey Research', Information Technology, Learning, and Performance Journal, 19 (1), 43-50.

- Barthès, C. (2005), Méthode et Outils pour Bâtir une Stratégie Touristique de Territoire, Guide D'ingénierie Territoriale, La Lettre du Cadre Territorial, Voiron.

- Bédard, F. (2011), 'L'excellence des Destinations', Téoros : Revue de Recherche en Tourisme, 30 (1), 9-11.

- Bertaux, D. (1981), Biography and Society: the Life History Approach in the Social Sciences, Sage Publications, Beverly Hills, California.

- Bigne, J. E., Sanchez, M. I. and Sanchez, J. (2001), 'Tourism Image, Evaluation Variables and After Purchase Behavior: InterRelationship', Tourism Management, 22 (6), 607-616.

- $\quad$ Bland, J. M. and Altman, D. G. (1997), 'Statistics Notes: Cronbach's Alpha', BMJ, 314 (7080), 570-572.

- Caillaud, S. and Flick, U. (2016), Triangulation méthodologique, ou comment penser son plan de recherche, Les Représentations Sociales: Théories, Méthodes et Applications, Bonnefoy, L., Lo Monaco, G., Delouvée, S. and Rateau, P. (ed), De Boeck, Brussels.

- Carricano, M. and Poujol, F. (2008), Analyse de Données avec SPSS, Pearson, Paris.

- Chen, C. F. and Tsai, D. C. (2007), 'How Destination Image and Evaluative Factors Affect Behavioral Intentions?', Tourism Management, 28 (4), 1115 - 1122.

- Chi, C. G. Q. and Qu, H. (2008), 'Examining the Structural Relationships of Destination Image, Tourist Satisfaction and Destination Loyalty: An Integrated Approach', Tourism management, 29 (4), 624-636.
- Chimi, C. J. and Russell, D. L. (2009), 'The Likert-type scale: A proposal for improvement using quasi-continuous variables', Proceedings of the Information Systems Education Conference, ISECON, ISSN: 15427382 November 2009, Washington, DC, 26, 110.

- Chon, K. S. (1990), 'The Role of Destination Image In Tourism: A Review and Discussion', The Tourist Review, 45 (2), 2-9.

- Chon, K. S. (1991), 'Tourism Destination Image Modification Process: Marketing Implications', Tourism Management, 12 (1), 68-72.

- Creswell, J. W. (2009), Research Design: Qualitative, Quantitative, and Mixed Methods Approaches, Sage publications, Thousand Oaks, California.

- Crompton, J. L. (1979), 'An Assessment of the Image of Mexico as a Vacation Destination and the Influence of Geographical Location upon the Image', Journal of Travel Research, 18 (4), 18-23.

- Crotts, J. C. (2004), 'The Effect of Cultural Distance on Overseas Travel Behaviors', Journal of Travel Research, 43 (1), 83-88.

- Denzin, N. and Lincoln, Y. (2017), Introduction: The discipline and practice of qualitative research, Handbook of Qualitative Research, Denzin, N. and Lincoln, Y. (ed), Sage Publication, Thousand Oaks, California.

- Durand, C. (2003), L'analyse Factorielle et L'analyse de Fidélité, Université de Montréal, Canada.

- $\quad$ Echtner, C. M. and Ritchie, J. R. B. (1991), 'The Meaning and Measurement of Destination Image', Journal of Tourism Studies, 2 (2), 2-12.

- Embacher, J. and Buttle, F. (1989), 'A Repertory Grid Analysis of Austria's Image as a Summer Vacation Destination', Journal of Travel Research, 27 (3), 3-7.

- Fortin, M. F., Côté, J. and Fillion, F. (2005), Les Approches Quantitative et Qualitative, Fondements et Etapes du Processus de Recherche, Chenelière Éducation, Montréal.

- Frochot, I. and Legohérel, P. (2017), Marketing du Tourisme, Dunod, Paris.

- Gartner, W. C. (1989), 'Tourism Image: Attribute Measurement of State Tourism Products Using Multidimensional Techniques', Journal of Travel Research, 28(2), 16-20.

- Gartner, W. C. (1993), 'Image Formation Process', Journal of Travel and Tourism Marketing, 2 (2/3), 191-215.

- George, B. and Alexandru, N. (2005), 'Holiday Attachment: The Construct and its Measurement', Anfiteatru Economic, 18, 2438. 
- George, B. P. and George, B. P. (2004), 'Past Visit and the Intention to Revisit a Destination: Place Attachment as the Mediator and Novelty Seeking as the Moderator', The Journal of Tourism Studies, 15 (2), 51-66.

- Gosavi, A. (2015), 'Analyzing Responses from Likert Surveys and Risk-adjusted Ranking: A Data Analytics Perspective', Complex Adaptive Systems, 61, 24-31.

- Griffero, T. (2013), "The atmospheric "skin" of the city', [online], Ambiances. [Retrieved August 15, 2020], Available: https://journals.openedition.org/ambiances/ 399

- Gunn, C. (1988), Vacationscape: Designing Tourist Regions, Van Nostrand Reinhold, New York.

- Habing, B. (2003), 'Exploratory factor analysis theory and application', [Online], [Retrieved April 22, 2020], Available: https://www.let.rug.nl/nerbonne/teach/rem a-stats-meth-seminar/Factor-AnalysisKootstra-04.PDF

- Hunt, J. D. (1971), Image: a Factor in Tourism, Unpublished Ph.D. dissertation, Fort Collins: Colorado State University.

- Hunt, J. D. (1975), 'Image as a Factor in Tourism Development', Journal of Travel Research. 13 (13), 1-7.

- Jenkins, O. H. (1999), 'Understanding and Measuring Tourist Destination Image', International Journal of Tourism Research, 1 (1), 1-15.

- Kim, H. and Richardson, S. L. (2003), 'Motion Picture Impacts on Destination Images', Annals of Tourism Research, 30 (1), 216-237.

- Kotler, P., Bowen, J. T., Makens, J. and Baloglu, S. (2017), Marketing For Hospitality And Tourism, Pearson, Harlow.

- Lawson, F. and Baud-Bovy, M. (1977), Tourism and Recreational Development, Architectural Press, London.

- Lee, J. (2003), Examining the Antecedents of Loyalty in a Forest Setting: Relationships among Service Quality, Satisfaction, Activity Involvement, Place Attachment, and Destination Loyalty, Unpublished Dissertation, The Pennsylvania State University, Pennsylvania.

- Leisen, B. (2001), 'Image Segmentation: The Case of a Tourism Destination', Journal of Services Marketing, 15 (1), 49-66.

- Lozato-Giotart, J. P., Leroux, E. and Balfet, M. (2014), Management du Tourisme : Territoires, Offres et Stratégies, Pearson Education, France.
- MacCannell, D. (1976), The Tourist: A New Theory of the Leisure Class, Berkeley: University of California Press.

- MacKay, K. J. and Fesenmaier, D. R. (1997), 'Pictorial Element of Destination Image Formation', Annals of Tourism Research, 21(3), p. 537-565.

- Marchat, A. and Camelis, C. (2017), 'L'image de Marque de la Destination et son Impact sur les Comportements Post-Visite des Touristes', Gestion et Management Public, 5 (1), 43-58.

- Moore, R. L. and Graefe, A. R. (1994), 'Attachments to Recreation Settings: The Case of Rail-Trail Users', Leisure Sciences, 16 (1), 17 31.

- Moutinho, L. (1987), 'Consumer Behavior in Tourism', European Journal of Marketing, 21 (10), 5-44.

- Norman, G. (2010), 'Likert Scales, Levels of Measurement and the "Laws" of Statistics', Advances in Health Sciences Education, 15 (5), 625-632.

- $\quad$ Oliver, R. L. (1997), Satisfaction: A Behavioral Perspective on the Consumer, McGraw-Hill, New York.

- Patton, M. Q. (1990), Qualitative Evaluation and Research Methods, Sage Publications, Newbury Park, California.

- Piriou, J. (2011), 'Le Haut-Lieu touristique : Un Cadre d'Analyse de l'Excellence d'une Destination', Téoros : Revue de Recherche en Tourisme, 30 (1), 25-32.

- Prayag, G. and Ryan, C. (2012), 'Antecedents of Tourists' Loyalty to Mauritius: The Role and Influence of Destination Image, Place Attachment, Personal Involvement, and Satisfaction', Journal of Travel Research, 51 (3), 342-356.

- Public service. (2020), [Online], Collinsdictionary.com. [Retrieved August 15, 2020],

Available: https://www.collinsdictionary.co $\mathrm{m} /$ dictionary/english/public-service/related

- Pritchard, M. P. (1998), 'Responses to Destination Advertising: Differentiating Inquiries to a Short, Getaway Vacation Campaign', Journal of Travel and Tourism Marketing, 7 (2), 31-51.

- Qu, H., Kim, L. and Im, H. (2011), 'A Model of Destination Branding: Integrating the Concepts of the Branding and Destination Image', Tourism Management, 32 (3), 465-476.

- Richardson, S. and Crompton, J. L. (1988), 'Cultural Variations In Perceptions of Vacation Attribues', Tourism Management, 9 (2), 128136. 
- Savoie-Zajc, L. (1997), L'entrevue semidirigée, Recherche Sociale: de la Problématique à la Collecte des Données, Gauthier, B. (ed), Presses de l'Université du Québec, Sainte-Foy.

- Snijkers, G. J. M. E. (2002), Cognitive Laboratory Experiences: On Pre-testing Computerised Questionnaires, Utrecht University, the Netherlands.

- Streiner, D. L. (2003), 'Starting at the Beginning: an Introduction to Coefficient Alpha and Internal Consistency',Journal of Personality Assessment, 80 (1), 99-103.

- Stylidis, D., Shani, A. and Belhassen, Y. (2017), 'Testing an Integrated Destination Image Model across Residents and Tourists', Tourism Management, 58, 184-195.

- Suchman, E. (1968), Evaluative Research: Principles and Practice in Public Service and Social Action Programs, Russell Sage Foundation, New York.

- Sullivan, G. M. and Artino, Jr. A. R. (2013), 'Analyzing and Interpreting Data from LikertType Scales.' Journal of Graduate Medical Education, 5 (4), 541-542.

- Tashakkori, A. and Teddlie, C. (2010), Handbook of Mixed Methods in Social \& Behavioral Research, Sage, Thousand Oaks, California.

- Tapachai, N. and Waryszak, R. (2000), 'An Examination of the Role of Beneficial Image in
Tourist Destination Selection', Journal of Travel Research, 39 (1), 37-44.

- Tasci, D. A. and Gartner, W. C. (2007), 'Destination Image and Its Functional Relationships', Journal of Travel Research, 45 (4), 413-425.

- Telisman-Kosuta, N. (1994), Tourist destination image, Tourism Marketing and Management Handbook, Witt, S. and Moutinho, L. (ed), Prentice Hall, Cambridge.

- Veasna, W. and Huang, C. H. (2013), "The Impact of Destination Source Credibility on Destination Satisfaction: The Mediating Effects of Destination Attachment and Destination Image', Tourism Management, 36, 511-526.

- Violier, P. (2007), 'Tourisme et Médias: Regard d'un Géographe', Le Temps des Médias, 1 (8), 159-170.

- Wagle, U. (2000), 'The Policy Science of Democracy: The Issues of Methodology and Citizen Participation', Policy Sciences, 33 (2), 207-223.

- Wang, C. Y. and Hsu, M. K. (2010), 'The Relationships of Destination Image, Satisfaction, and Behavioral Intentions: An Integrated Model', Journal of Travel \& Tourism Marketing, 27 (8), 829-843.

- Yuksel, A., Yuksel, F. and Bilim, Y. (2010), 'Destination Attachment: Effects on Customer Satisfaction and Cognitive, Affective and Conative Loyalty', Tourism Management, 31 (2), 274-284.

\section{Appendix 1. The interview guide}

\section{General points:}

1. Is the tourism sector important for the region?

2. How much were tourism revenues in 2018 ?

3. How many jobs does the tourism industry generate in Tyre?

4. What is the budget allocated to the tourism sector in Tyre?

5. What are the nationalities of the tourists visiting Tyre?

\section{Tourism sector in Tyre:}

6. What are the main tourism activities in the city of Tyre and which ones do you emphasize?

7. What are the assets of the city of Tyre?

8. What are your objectives in respect of tourism for the next couple of years?

9. What is hindering the development of this sector?

10. How do you go about promoting tourism in Tyre? Are you satisfied with your current actions? What more actions can you take?

11. What image does the city of Tyre reflect to tourists?

12. How do you communicate about Tyre as a destination? By what means?

14. How important is the International Tyre Festival to tourism?

15. Which Lebanese tourist cities do you think Tyre competes with?

16. How does Tyre stand in relation to other cities in Lebanon?

17. How many hotels and restaurants are there in Tyre?

18. How important is the inclusion of the city of Tyre on the UNESCO World Heritage List?

19. What is special about the archaeological sites in Tyre?

20. How are the entry prices to tourist sites set?

21. How are the sites in Tyre maintained?

Batoul TAMIM, Walid ABOU-KHALIL and Eliane KHALIFE (2021), Journal of Marketing Research and Case Studies, DOI : 10.5171/2021.773594 
22. What is Tyre's position in relation to other nearby archaeological sites?

Appendix 2. The questionnaire

1. How likely are you to recommend visiting Tyre to a friend or a colleague? Not Likely Very Likely

\begin{tabular}{|l|l|l|l|l|}
\hline 1 & 2 & 3 & 4 & 5 \\
\hline & & & & \\
\hline
\end{tabular}

Please pick just one choice

2. How many times have you visited Tyre (including this time)?

Once (it is the first time)

$O$ Twice and more

O I don't remember

3. How long have you stayed in your last visit to Tyre?

O One day

O One weekend

O One week

O More than a week

4. What did you like the most about the city?

O The cultural heritage (ruins, souks...)

The beach and the port

The nightlife

O Other:

5. What other touristic destinations have you visited in Lebanon?

O Beirut

O Saida

O Jbeil

O Baalbek

O Other:

6. What are the reason that prompted you to visit Tyre?

Its natural attractions (climate, beaches, landscapes ...)

Its cultural and tourist attractions (historical monuments and sites ...)

$O$ Its events and festivals

Its old neighborhoods

O Other:

7. How did you hear about Tyre?

O Brochures and documents

O Internet and social network

O TV report and documentary

Word of mouth (from people)

O Other:

8. Please indicate your degree of agreement for the statements below by checking one of the five response categories 


\begin{tabular}{|l|c|c|c|c|c|}
\hline & $\begin{array}{c}\text { Strongly } \\
\text { agree }\end{array}$ & Agree & $\begin{array}{c}\text { Neither agree } \\
\text { nor disagree }\end{array}$ & Disagree & $\begin{array}{c}\text { Strongly } \\
\text { disagree }\end{array}$ \\
\hline $\begin{array}{l}\text { The histonical heritage of Tyre } \\
\text { is very rich }\end{array}$ & 0 & 0 & 0 & 0 & 0 \\
\hline $\begin{array}{l}\text { The tourist sites of Tyre are } \\
\text { impressive }\end{array}$ & 0 & 0 & 0 & 0 & 0 \\
\hline Tourism in Tyre is varied & 0 & 0 & 0 & 0 & 0 \\
\hline $\begin{array}{l}\text { There is a cultural diversity in } \\
\text { Tyre Festival is an }\end{array}$ & 0 & 0 & 0 & 0 & 0 \\
\hline $\begin{array}{l}\text { The Tyre Finteresting event } \\
\text { ine nightlife in Tyre is } \\
\text { enjoyable }\end{array}$ & 0 & 0 & 0 & 0 & 0 \\
\hline $\begin{array}{l}\text { It has neighborhoods with old } \\
\text { and traditional character }\end{array}$ & 0 & 0 & 0 & 0 & 0 \\
\hline $\begin{array}{l}\text { The beach of Tyre is among } \\
\text { one of the best in Lebanon }\end{array}$ & 0 & 0 & 0 & 0 & 0 \\
\hline The city of Tyre is clean & 0 & 0 & 0 & 0 & 0 \\
\hline $\begin{array}{l}\text { Hotels in Tyre offer a } \\
\text { satisfying service }\end{array}$ & 0 & 0 & 0 & 0 & 0 \\
\hline The local cuisine is healthy & 0 & 0 & 0 & 0 & 0 \\
\hline $\begin{array}{l}\text { Parking lots in Tyre are a real } \\
\text { problem }\end{array}$ & 0 & 0 & 0 & 0 & 0 \\
\hline $\begin{array}{l}\text { The local population of Tyre is } \\
\text { welcoming and friendly }\end{array}$ & 0 & 0 & 0 & 0 & 0 \\
\hline Tyre is a vivid city & 0 & 0 & 0 & 0 & 0 \\
\hline $\begin{array}{l}\text { Road congestion in Tyre is a } \\
\text { serious problem }\end{array}$ & 0 & 0 & 0 & 0 & 0 \\
\hline Tyre is pedestrian friendly city & 0 & 0 & 0 & 0 & 0 \\
\hline Tyre is a safe city & 0 & 0 & 0 & 0 & 0 \\
\hline $\begin{array}{l}\text { The cost of living in Tyre is low } \\
\text { The }\end{array}$ & 0 & 0 & 0 & 0 & 0 \\
\hline
\end{tabular}

Please pick just one choice

9. Are you visiting Tyre?

O Alone

With your family

In couple

$O$ With friends

O Other:

10. Daily budget of stay in Tyre (except accommodation):

○ 10-50\$

○ 51-100\$

○ 101-150\$

O More than $151 \$$

11. Age:

O 18 - 24 years

O 25 - 34 years

O 35 - 44 years

O 45 - 54 years

O 55 - 64 years

O 65 and over

12. Gender:

O Male

O Female

13. Living place:

O Lebanon

O Abroad

Please Specify (city):

Please Specify (country):

14. Family situation:

O Single

O Married 
O Divorced

O Widowed

15. Education level:

High school

Technical studies

University studies

O Other: .............

16. Profession:

Intellectual profession

Entrepreneur or liberal profession

Omployee

O Worker

O Retired

O Student

Unemployed

O Other: ..............

17. Monthly income:

O Under $\$ 1000$

○ \$1000 - \$1500

○ $\$ 1500$ - $\$ 2000$

○ $\$ 2000$ - $\$ 2500$

○ $\$ 2500$ - $\$ 3000$

Over $\$ 3000$

18. Nationality:

Batoul TAMIM, Walid ABOU-KHALIL and Eliane KHALIFE (2021), Journal of Marketing Research and Case Studies, DOI : 10.5171/2021.773594 